\title{
Conversation with Boxing Gloves Between Chamecki and Lerner $^{1}$
}

Cristiane Bouger

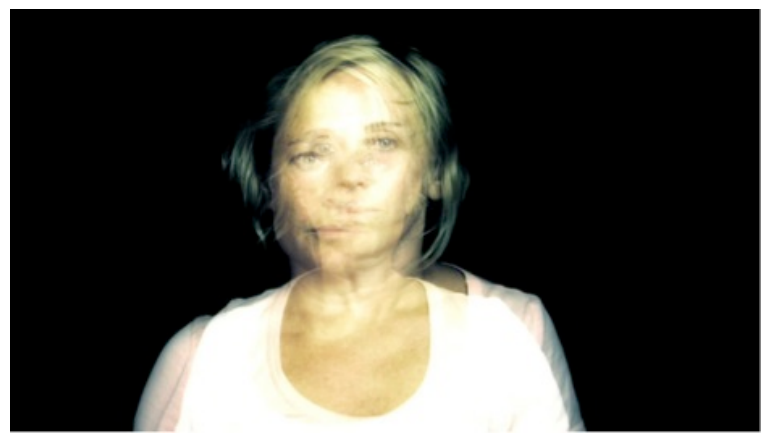

Figure 1:

Rosane Chamecki and Andrea Lerner on the video Conversation with Boxing Gloves Between Chamecki and Lerner

(c) chameckilerner, 2009

In 2009 the biennial Performa celebrated the centenary of the publication of the Futurist Manifesto, written by the Italian poet Filippo Tommaso Marinetti. Performa 09 - The Third Biennial of New Visual Art Performance, directed by art historian and critic RoseLee Goldberg, was held in New York City from November 1-22.

Marinetti's manifesto was published in Paris on the first page of the daily newspaper Le Figaro on February 20, 1909. The influential text would introduce one of the most provocative and radical artistic movements of the last century, leading the Futurist practices in the decades to follow. While seminal for the development of performance works and avant-garde practices that emerged later during the twentieth century, ${ }^{2}$ however, Futurism was also profoundly polemical, not only because of its extravagant ideas, but because of Marinetti's sexist and fascist perspective through which he exalted "the destructive gesture of freedom-bringers" and praised war as "the world's only hygiene." ${ }^{3}$

The revolutionary artistic ideas originated by the Futurists manifestos in Italy, a couple of years before World War I, remain controversial. The will to "destroy" the past and scorn all established structures such as museums and academies led the Futurists to envision new directions to the arts in the twentieth century. As RoseLee Goldberg writes, "Futurist Manifestos left no part of modern life untouched, probing and provoking, inventing and challenging, and proposing and projecting new ways to eat, sleep, fly and dream." ${ }^{\prime \prime}$

The controversy concerning Futurism served as the starting point for the creation of the video, Conversation with Boxing Gloves Between Chamecki and Lerner. The work was created by choreographers Rosane Chamecki and Andrea Lerner for the ambitious Futurist Life Redux, a Performa project that recreated Vita Futurista, the first 
and only Futurist film ever made. In the following, I analyze how chameckilerner embraced some characteristics of Futurism to pay homage to the legacy of the movement and simultaneously address a critical response to the Futurists' notorious exaltation of violence and war.

\section{Vita Futurista}

Vita Futurista, originally filmed by Arnaldo Ginna in $1916,{ }^{5}$ is considered the only official Futurist film ever made. It presented many of the ideas proposed in 1916 by The Futurist Cinema manifesto, co-written by F.T. Marinetti, Bruno Corra, Emilio Settimelli, Arnaldo Ginna, Giacomo Balla, and Remo Chiti. The project Futurist Life Redux, curated by Lana Wilson and Andrew Lampert, was part of the celebratory Futurist program of Performa 09. Inspired by Vita Futurista, the Redux project involved eleven filmmakers and video artists. Each of them was invited to recreate one of the different segments of the original 40-minute feature, of which there are no remaining copies. The segment titles were distributed randomly among the artists.

As stated in the program notes of Futurist Life Redux, the original film was thought to be comprised "of at least eleven independent segments conceived and written by different Futurist artists." A single-sentence description of the original segments and a few stills constituted the point of departure for the artists to recreate their own re-imagined version of the Futurist film.

Among the artists invited to be part of the project ${ }^{6}$ were the choreographers and filmmakers Rosane Chamecki and Andrea Lerner, who brought in filmmaker Phil Harder to collaborate with their film. Chamecki and Lerner initiated the transition from dance to filmmaking in 2007. In the following year they were among the recipients of the Guggenheim Fellowship, which allowed the duo to work on two video productions: The Collection (2011) and The Line (unfinished to date). For the Performa 09 commission,7 their short, Conversation with Boxing Gloves Between Chamecki and Lerner, re-imagined the Vita Futurista segment, Discussion with Boxing Gloves Between Marinetti and Ungari.

As with the other artists who were part of the Redux project, chameckilerner received a small budget, the title, and a still of the original segment that they should recreate within a six-week schedule. The still, Discussion with Boxing Gloves Between Marinetti and Ungari, shows Marinetti in a movement position that suggests he has just punched Ungari, who has his back turned to the camera. In 2007,8 Rosane Chamecki and Andrea Lerner had created a video work inspired by boxing fight; to accomplish their Performa assignment without repeating themselves, they needed to rethink boxing by approaching it differently this time. They also asked themselves many questions concerning how to create a significant piece inspired by an artistic movement with which they had critical disagreements, since the sexist and pro-war ideas presented in the Futurist manifestos were not endorsed by the duo. 
According to Lerner, ${ }^{9}$ one of their fundamental concerns was how they could look back at Futurism, especially if looking at the past meant a betrayal of the movement itself. Therefore, imagining how to be a Futurist in the very presentinstead of revisiting the Futurism's past-was a thought-provoking and exciting challenge. Lerner and Chamecki decided to use artistic attributes valued by Marinetti and the Futurists, such as speed, absence of drama, simultaneity, dynamism, and violence. They appropriated those characteristics subtly, and indeed efficiently, by subverting fighting to recreate its meaning.

\section{A Kinetic Film - Not a Video Dance Work ${ }^{10}$}

By naming their work Conversation with Boxing Gloves instead of adopting the title Discussion with Boxing Gloves, chameckilerner announce an altered approach to the violence suggested by the original film. Transgressing violence by blurring and reversing its own force, chameckilerner employ two main editing attributes: the overlapped position of the performers facing the camera and the reversed temporality of the action.

The four-minute video was recorded by Harder with a black background, showing Chamecki and Lerner centered on the frame. He filmed four takes of four minutes of each dancer with no cuts, making eight takes. From that point, the artists overlapped the different combinations of footage they had at hand until selecting one take of each of them for the final editing.

The video action comprises a boxing fight that develops into a dance. We see two women in fight position, facing the camera and, by extension, in direct relation to the spectator. The images of Chamecki and Lerner are merged, simultaneously creating unity and diffusion of their identities. The action of fighting is developed until the point the fight positions turn into dance movements.

The inverted movement of the video is crucial to the subversion of the violence achieved by this work: the video was recorded with Lerner and Chamecki initially dancing, further developing the dance into a boxing fight. The video then was edited showing the footage played backwards; what we see is an opposite sequence of a fight transformed into dance. Because of this temporal manipulation, the violent movement of the punch is reversed, pulled toward the direction of the fighter who threw it, instead of toward her opponent (or spectator). When the attack is pulled back to the aggressor and subtly transformed into dance, the violence is subverted using the punch's own dynamics and speed.

Since the performers face the camera, the spectator becomes involved in the action, in the sense that one is facing the fighters and the blurred movements of their dissolved images. Sometimes it feels that it is me-as the viewer-who is hit by the punch and who sees the opponent dissolve into another woman's body. This impression does not happen by chance. According to Lerner, they wanted not only to attain a perceptual weirdness of the movement expressed on the video, but also to 
incite a certain physicality in the viewer, granting the spectator the perspective of the fighter's adversary, in such a way that one could not watch the action passively.

The structure of the work is very simple, since it comprises two overlapped one-take sequences of a dance/fight movement. Still, Conversation with Boxing Gloves Between Chamecki and Lerner reverberates as a conceptual and physical response to the artists' initial question about how to look back at the Futurism: the speed so valued by the Futurists - a new mechanical quality in that context-is used to reverse the past into the present. In this regard, chameckilerner makes both a tribute to the Futurists and a statement about the impossibility of their radical wish to destroy the past.

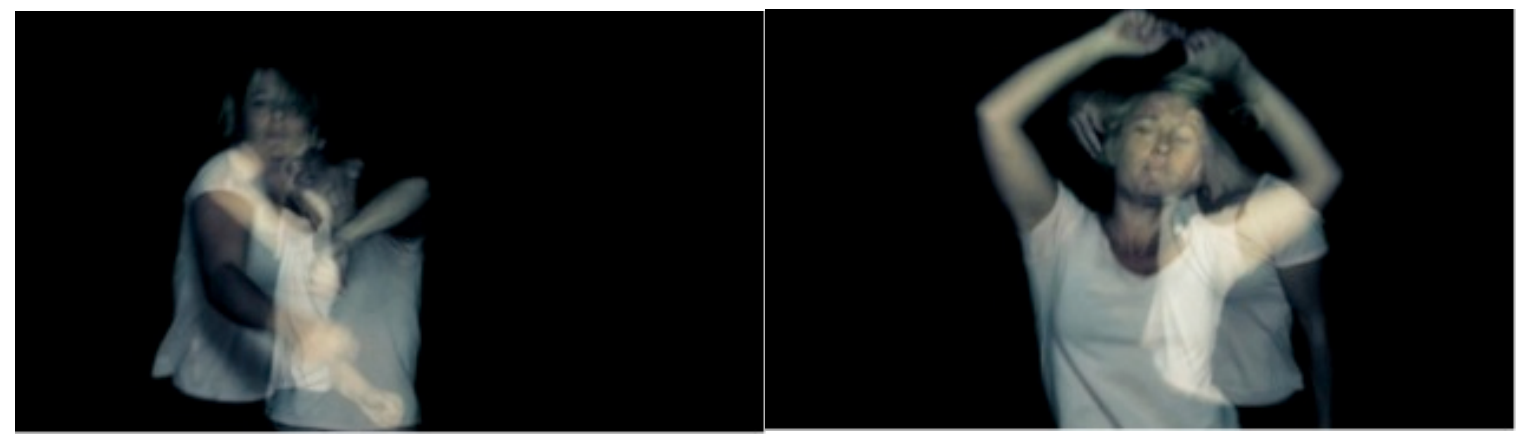

Figures 2 and 3 :

Stills of the video Conversation with Boxing Gloves Between Chamecki and Lerner

(c) chameckilerner, 2009

Considering they did not create the choreography for the camera, but rather a film based on a real action, Lerner situates the creation of Conversation with Boxing Gloves closer to a live art concept than to a video dance approach. Still, she emphasizes the kinetic quality of chameckilerner's work for the camera. In an interview granted for this article, Lerner stated:

Working with film has been an extension of what we were doing [in dance], but we are questioning ourselves about which direction we will head to. We know there is a kinetic quality that is inevitable for us because this is the way we see the world. So far, body and movement are the focus of our films.... A lot of people ask us if we are now making video dance works. We do not have any interest in making video dance. We are making films. ${ }^{11}$

She clarified that her work with Rosane Chamecki always evolved from an action and not from a choreography or narrative. Even in chameckilerner's earlier trajectory, their choreographies were created from a specific action that imposed the development of the dance score.

Considering that one of the crucial factors in performance and live art works relies on the performer's ability to attune and embody a compelling state of presence, 
Chamecki expands Lerner's approach, pointing out that in their dance works for the stage, chameckilerner always attempted to recapture, in front of the audience, the momentum whereby, as in their rehearsals, liveness and presence were unquestionable. ${ }^{12}$ Nonetheless, this re-embodiment is not something easily achieved, and sometimes it hardly reoccurs in the works that are re-performed. From this perspective, Chamecki understands that creating videos allows them to capture these moments, which otherwise would vanish unseen. In that sense, Chamecki ponders if a performance for the camera can, in some cases, comprise more "liveness" than a live performance.

With Conversation with Boxing Gloves chameckilerner created a distinctive and effective reinterpretation of some of the attributes of The Futurist Cinema manifesto. Interchangeably blurring and defining their own practice, the artists subverted and recreated meaning to make explicit both the fragility and strength of Futurist concepts in a time in which violence, speed, and simultaneity reached completely new dimensions and influence in contemporary life.

\section{Notes}

1. An earlier version of this article was published as Cristiane Bouger, "Conversa Futurista entre Chamecki e Lerner," Idanca (2010), http://idanca.net/conversafuturista-entre-chameki-e-lerner/. In addition, an extended version of this article was published in 2012; see Cristiane Bouger, "A Discussão Entre Marinetti e Ungari Reimaginada por chameckilerner," in dança em foco-Ensaios Contemporâneos de Videodança, eds. Paulo Caldas, Leonel Brum, Eduardo Bonito, and Regina Levy. (Rio de Janeiro: Aeroplano, 2012), 167-191.

2. Rainey refers to Futurism as "a paradigm for countless movements that followed, some embodying the most vital currents among the twentieth-century arts (Vorticism, Dadaism, and Surrealism are only a few of them)." Nevertheless, stating that Futurism "remains one of the great dead ends of modernism," Rainey criticizes the preoccupation of scholars and critics "with establishing genealogies of modernism and the avant-garde." See Lawrence Rainey, Christine Poggi, and Laura Wittman, eds., Futurism: an anthology (New Haven and London: Yale University Press, 2009), 1, 46.

3. F. T. Marinetti, "Manifeste du Futurisme" as published in Le Figaro in 1909, in RoseLee Goldberg, Performance Art: From Futurism to the Present (New York: Harry N. Abrams, Incorporated, 1988), 10. For the English translation of Marinetti's manifesto, see Rainey, Poggi, and Wittman, Futurism, 49-53. 
4. RoseLee Goldberg, "Music for 16 Futurist Noise Intoners," a Performa 09 Commission, (New York: Program Notes, 2009).

5. Lana Wilson and Andrew Lampert, "Futurist Life Redux," in RoseLee Goldberg, Perfoma 09 - Back to Futurism (New York: Performa Publications, 2011), 94-97.

6. Futurist Life Redux was comprised of works by Aida Ruilova, Lynn Hershman Leeson, Michael Smith with Bill Haddad, Shannon Plumb, George Kuchar, Shana Moulton, chameckilerner (with Phil Harder), Ben Coonley, Trisha Baga, Matthew Silver and Shoval Zohar (The Future), and Martha Colburn.

7. A Performa Commission with SFMOMA and Portland Green Cultural Projects.

8. The video mentioned was part of the dance work EXIT, presented at The Kitchen, in New York, May 2007. EXIT marked chameckilerner's transition from dance to filmmaking.

9. Although the work in question is more accurately defined as video, Rosane Chamecki and Andrea Lerner constantly refer to their work as "short films." This definition also appears on their website and program notes. In this article, I opted to use the term "film" only when I refer to chameckilerner's approach of their own practice. See chameckilerner, "Films by chameckilerner," accessed June 15, 2014, http://www.chameckilerner.com/film.html.

10. In the first version of this article I opted to employ the term kinesthetic. However, the term kinetic is more frequently used in dance-theoretical sources and it seems more accurate to refer to the body in movement in chameckilerner's videos. See Bouger, op. cit., accessed June 15, 2014, http://idanca.net/conversa-futurista-entrechameki-e-lerner/.

11. Interview conducted by the author with Andrea Lerner (New York, 2009). Quote translated by the author. In the original recorded conversation in Portuguese, Andrea Lerner states: "Trabalhar com filme está sendo uma extensão do que estávamos fazendo [na dança], mas estamos nos questionando sobre qual direção tomar. Nós sabemos que há uma relação cinestésica que é inevitável para nós porque é assim que vemos o mundo. Corpo e movimento são o foco dos nossos filmes até aqui... Muitas pessoas nos questionam se estamos fazendo vídeodança. Nós não temos o mínimo interesse em fazer vídeodança. Estamos fazendo filmes."

12. Conversation by phone with Rosane Chamecki on April 17th, 2010. 


\section{References}

Bouger, Cristiane. "Conversa Futurista entre Chamecki e Lerner." Idanca. April, 2010. http://idanca.net/conversa-futurista-entre-chameki-e-lerner/.

---. "A Discussão entre Marinetti e Ungari Reimaginada por chameckilerner." In dança em foco-Ensaios Contemporâneos de Videodança, edited by Paulo Caldas, Leonel Brum, Eduardo Bonito, and Regina Levy, 167-191. Rio de Janeiro: Aeroplano, 2012.

Goldberg, RoseLee. Performance Art: From Futurism to the Present. New York: Harry N. Abrams, Incorporated, 1988.

---. Performa 09 - Back to Futurism. New York: Performa Publications, 2011.

Merjian, Ara H.. "Futurist Past." Artforum. November 2, 2009. http://artforum.com/film/id=24092.

Rainey, Lawrence, Christine Poggi, and Laura Wittman, eds. Futurism: an anthology. New Haven and London: Yale University Press, 2009.

Russo, Anna Carla. "Vita Futurista: Un Film Fantasma." Tesi online. http://www.tesionline.it/v2/appunto-sub.jsp?p=8\&id=76.

Sontag, Susan. In Under the Sign of Saturn: Essays. New York: Picador USA, 2002. 